DOI: $10.15503 /$ jecs20151.167.184

\title{
USING EDUCATIONAL MARBLE GAMES IN GERMAN LANGUAGE TEACHING
}

\author{
Hasan CoşKun \\ Gaziosmanpaşa University, Faculty of Education, \\ Department of Curriculum and Instruction, Tokat Turkey \\ hasan.coskun@gop.edu.tr \& dr.hasancoskun@gmx.de
}

\begin{abstract}
The aim of this article is to show how German students can be motivated by learning games. Apart from the development and didacticisation of the learning game "Marbles", the attitude of Turkish families and language teaching educational establishments and the support of the DaF lessons by German mediating institutions in Turkey will be considered. The attitude of Turkish families to learning foreign languages is mostly positive. Turkish educational authorities and those responsible for education take various measures to expand foreign language teaching availability in the schools. German institutions which provide teachers (Goethe-Institut, ZfA, DAAD) promote the improvement of German teaching in Turkey. Nevertheless, the quality of German teaching is not satisfactory mostly because the available teachers are not adequately qualified, teacher training is remote from practice, the quality of text books and teaching materials, the traditions of learning, the excessively large classes, inadequate learning environment (language cabinets and equipment), the nature and method of central examinations (multiple choice) and their significance in the Turkish educational system. In the long-term, this leads to frustration in both teachers and students. The Turkish educational authorities initially took measures to expand the availability of language teaching in the course of harmonisation of the Turkish educational system to that of the EU e.g. the introduction of a second foreign language. German mediating institutions ensure reasonable further training for teachers locally and in Germany and support the creation of teaching materials etc.

The Ministry of Education in Turkey, has started to take measures for students to learn other languages such as German, French, Russian, Spanish, Japanese, Italian, Arabic, ethnic languages in Turkey, et cetera in the educational institutions in addition to English. For example, in the Anatolian high schools two foreign languages are taught. The Board for Higher Education in Turkey, has introduced second foreign language lessons in foreign language teacher programs, envisioned to be taken for three semesters, in order for the language teachers to gain experience in the field of two languages. Private education institutes are emphasizing that they are teaching more than one foreign language in order to draw more students. Families make an economic sacrifice for their children in order for them to learn foreign languages. It is observed that in some districts of certain major cities, teaching of foreign languages has started to be given as early as at kindergarten level. In Turkey, German is preferred as the second foreign language in general. Nowadays, German is the second preferred language from primary to high school in Turkey. The quality of German language lessons should be increased for more students to select German as the second foreign language in the coming years. Despite all these efforts, teaching foreign language is not up to the desired level in Turkey (Bayraktaroğlu, 2014, pp. 9-14; Demircan, 2014, pp. 17-22). For that reason, it is important that motivating teaching methods and teaching materials be developed for German teaching.
\end{abstract}

Keywords: kitchen appliances, teaching German as a foreign language, educational marble game, exercise types, implementation 


\section{METHOD}

This study is an experimental research (Yıldırım \& Şimşek, 2006). The researcher began to design educational games at the beginning of the 1990's in order to draw the attention of students to lessons and to make sure that they retain what is taught. These games were developed in the Gazi University in Ankara and tested at the German School in Ankara, and some other Turkish schools and Universities. Expert opinions were taken both during the design of the educational games and in the implementation stages. Photographs were taken during the implementation of the games, reports were prepared, and notes were taken during the observations. This research was conducted during the 2013/2014 academic year on 84 students who had selected German as a second foreign language at the Hacettepe University, Faculty of Education, Department of Foreign Language Education, Division of English Language Teaching. The subject of the lesson was kitchen appliances (cf. Annex). Because the kitchen is one of the topics most frequently discussed in foreign language lessons. According to the result of this study, the students were found successful in the courses in which the games are applied, in comparison with the courses with traditional methods (Coşkun, 2013, pp. 151-169).

\section{THE CURRENT STATUS OF THE GERMAN TEACHERS AND LESSON IN TURKEY}

Before proceeding to the studies to be made with the marble games, we will briefly describe the current status of the German Teachers and lesson in Turkey. In doing so we will take advantage of the report dated, 2013 and the experiences of the Turkish-German Cultural Affairs Association (Ankara office).

The Education Cooperation Department of the German Cultural Center in Ankara, intends to support German lessons in Turkish schools and universities and to promote the German language. It is achieving these objectives through consultancy, projects aimed at those learning German and education programs prepared for teachers. It is supporting the learning of the German language in Turkish schools through the said programs.

The interest in German language has been numerically increasing since 2009. In keeping with the studies conducted on language in the European Union, multilingualism has been integrated into the Turkish education system. Consequently the German language is experiencing an increase in Turkey. The regular high schools in Turkey have been converted into Anatolian high schools which require a second foreign language. In the past years, there has been a significant increase in learning the German language in the state schools. However, there is no reliable statistical data in this regard.

The German language has primarily been able to take its place as a second foreign language and is taught for 2 lessons a week. Because it is given as a selective lesson, it is not possible to increase the number of lessons per week. However, the 
students rarely take the German language as a selective lesson for the time being. The German language has benefitted the most from the application of a mandatory second foreign language. $90 \%$ of the students select German language as their second foreign language.

One of the most important indicators in the interest shown in the German language is the appointment of new German teachers, unmatched almost anywhere in the world. During the first semester of the 2011/2012 academic year 230 teachers were hired and additionally 435 more German teachers were hired. During the second semester 165 more German teachers were appointed. These were primarily new graduates of the Faculty of Education. In addition to this, German language teachers, who worked as primary school teachers reverted to their main branch, the German language.

Another group is mentioned in the report. This group is comprised of teachers who graduated as English teachers and who took German as a second language for three semesters for two hours a per week. It is statistically unknown how many of the teachers in this group taught German in addition to English. However, it is estimated that there is a large group. Because, there is an insufficient number of German teachers in smaller settlements. English teachers are assigned there to teach English as a second foreign language.

The main target group of the Education Cooperation Department is the newly appointed German language teachers as in previous years. These newly appointed teachers are more ambitious than those who have returned from Germany and are more open to learning. The language fluency of the newly appointed teachers is comparatively lower. The reason for this is that they have learned the foreign language primarily in Turkey in the preparatory classes of a university. Because of this positive development, the Education Cooperation Department has arranged for a total of 4 basic training courses in order to develop language proficiency during this report period, two courses focused on methodology and two group work activities in Germany.

The teachers trained by the German Cultural Center in Ankara were employed in the regional teaching efforts with the instructions of the Ministry of Education. The Education Cooperation Department organized a teacher training program to support the results of the two supportive and developmental seminars.

The German Cultural Center in Ankara is organizing a series of seminars which provide massive training for the German language teachers. 8 sessions on annual long distance learning methodology courses and weekly seminars especially for the new German language teachers were held during this reporting period. In addition to this, some other works were conducted for specific groups. Seminars were given to teachers who learned German at preparatory classes in German Language Teaching Departments. These seminars were given in 12 universities once in a week during the period. "Problems of Measuring and Evaluation were discussed with the participation of one expert from the German Academic Exchange Service at Hacettepe University. In addition to these activities, scholarships for German schools to the German language teachers were given within the period of the report year. 
In the year 2013, the German Cultural Center in Istanbul hired a bus called the "German Language Bus" which travelled throughout Turkey for the expansion and promotion of the German language. This German language bus visited a school or an education centre every day to promote and adopt the German language to the students and showed them how to use the foreign language in games and competitions in a natural and free way. Robert Bosch Foundation was again a partner in the project held in the year 2012/2013. The project is supported by the Mercedes Benz Türk Inc. and "Bildungsoffensive Deutsch".

Other activities aimed at the learners were as follows: European Languages within the framework of EUNIC organized at the Black Sea Region, Doppel-U (Christian Wirich) arranged at Ankara region, Fairy Tale World exhibition and activities (Story Teller) and ("Here comes the sun") exhibition organized more by the program section.

"Schools: The Partners of the Future" executed under the framework of language works by the German Cultural Center of Ankara is very important. Education Cooperation Department primarily focuses on numeral works and therefore, the contents of the projects executed by the PASCH increase the quality in the longer term. As can be seen the German agencies in Turkey are exerting great efforts to promote the German language in Turkey. They know that the teachers play an important role in teaching a language. Therefore, they are exerting special care to train the teachers who will be teaching the German language in many ways. They should be guided to use the education games and show them how they can be used in teaching efficiently.

This report shoes that German mediating institutions are committed to the expansion and improvement of German language teaching in Turkey.

\section{PREPARATION OF THE EDUCATIONAL MARBEL GAME}

\section{As a learning material}

After having briefly outlined the situation of German teachers and the teaching of German, this section will deal with how the game "Marbles" has been didacticised and made useful for German language teaching.

\section{History of marble games}

The marble game is played extensively by children and young people in Anatolia as it is on many other regions of the world. Therefore, it is important to use the game of marbles in language teaching. From an anthropologic perspective, human beings have always been interested in rolling objects. Until the industrial production of marbles, humans used round stones, pebble stones and fruit food like nuts, walnuts and oranges. Obviously it is interesting for humans to try to hit an object from a certain distance. Diem $(2004$, p. 4) relates that the ancient Romans and Egyptians enjoyed playing marbles. Even today, games with marbles are still the most popular games for children and teenagers. There are many different marbles games worldwide. For example, Diem introduces 28 games of marbles in his book cited above. 
The author himself has experience from his childhood and youth. The idea of designing a game of marbles, used by the researcher in teaching language classes, came from an experience while living in an Anatolian village near Ankara. At that time, there were two common versions of a marble game in the researcher's village. In the first version, the aim was to hit the marbles laid out in a row on the ground. In the second version, marbles are rolled into a hole from a certain distance. Marbles are usually played outdoors but with the modifications made, marbles can be played indoors on carpets or on a table at home, for recreational activities at schools and so on.

\section{BASE CONSTRUCTION FOR THE MARBLE GAMES, DEVELOPED}

\section{For language classes}

The marble game was developed and designed as a package by the author. This package is comprised of different parts (units). The game board consists of a square of $65 \times 65 \mathrm{~cm}$. The wooden plate that serves as a game field is fixed in the middle of a wooden frame. The marble game case serves two functions. When the case is opened, the game field appears. When the case is closed, it becomes the container of the game tools (stones, marbles, dice, and game manual). The two wings of the case are mounted on to each other with two joints. There are also two locks on the case, which hold the case wings securely together after the case is closed, and there is also a handle to carry the case.

On the game field there are 24 spots to put the stones on, which are numbered and arranged in a circle. There is a hole in front of every spot where the marbles are thrown in. There are also four storage areas at the corners of the game board and, in front of every storage area; there are holes for the marbles. The 4 storages areas are numbered from 1 to 4 . Every storage area belongs to one player. For the game, twenty-four numbered stones, four standard sized marbles and a dice are needed. There is a Bosch emblem on one side of the stones and on the other side there is a picture depicting a field of various kitchen appliances. The kitchen appliances are inscribed in three languages.

\section{ACCESSORIES OF THE MARBLE GAMES}

The marble game consists of the following parts mentioned below:

- One case holding the marble game.

- Four marbles.

- 24 stones, each $6 \times 6 \times 1 \mathrm{~cm}$ in size.

- One dice.

- One game manual.

- Teaching materials.

To gather more information about the teaching materials (student sheet, referee sheet, puzzle) related to the theme of kitchen appliances one may consult the book "Learning Languages Through Games" (Coşkun, 2006, pp. 145-146, 214-219). The 
instructions for the use of the game can be modified according to the levels and needs of the target groups.

\section{MARBLE GAME RULES}

During the period that has elapsed, different training types and educational games compatible with the training types were developed. Every game has certain rules. The rules of the game must be brief, simple and easy to understand. The user should make the necessary arrangements to the rules of the game in the manner stated above. Here, the general rules of the game are given.

01 . This game of marbles is played with 4 players and one referee.

02 . The order of the players is determined with a dice. The player who throws the highest number sits in front of the smallest number of the storage and starts.

03. Before the game starts, all stones are thrown on the game board. During this process every player says the following by turns:
a) Now I will take a stone.
b) On the stone there is a picture.
c) The picture has the number ....
d) The picture means ... in Turkish ..., in English ... and ... in German
e) It's your turn.
f) Thank you very much.
g) Now I will take a stone and so on.

04. The marble is thrown from the middle of the game board (marked with START) or from the outer circle of the game board into the holes which are in front of the stones. (The player isn't allowed to move his hand).

The player says the following:

a) Now I will take my marble and throw it into a hole.

b) My marble isn't in a hole (in this case, it is the other player's turn) or my marble is in a hole.

c) I will flip over the stone in front of this hole.

d) On the stone there is a picture.

e) The picture has the number ....

f) The picture means ........... in Turkish in English and in German ....

g) I will put this stone back in the storage spot.

(The surface of the picture is on top and the Bosch emblem is on the bottom)

h) It's your turn.

i) Thank you very much.

j) Now I will take a marble and throw it into the hole and so on.

05. Each player gets a marble and puts it into the hole in front of his/her storage area.

06. Each player gets a student sheet.

07. The referee tells the first player to start.

08. After all the stones have been flipped over, or after the scheduled game time is over, every player puts the stones which he flipped over with the help of 
his/her student sheet into his storage area. As he/she does so, he/she says the following:

a) This is my stone.

b) Now I will take my stone.

c) On the stone there is a picture.

d) The picture has the number ....

e) The picture means in Turkish, in English and in German.

f) I will put this stone into my storage area.

g) It's your turn.

h) Thank you very much.

i) This is my stone and so on.

09. Teaching materials, supplementary games and practice forms will be introduced according to the sequence of events.

10. The referee determines the most successful player according to the referee sheet in which he/she entered the names of each player for each flipped stone and he announces at the end of the game.

11. The game board (game table) is cleared by all participants (Coşkun, 2013, pp. 157-158).

\section{GAME VARIATIONS}

The names of the kitchen appliances must be practiced by using different practice forms and through supplementary games. The use of various games and supplementary material in lessons helps the students focus on the subject matter for an extended period of time. The following games can be added and modified by the children:

1. Musical chairs.

2. Telephone game.

3. Card game.

4. Clothes line game.

The first three games have already been described in detail in the book "Learning Languages Through Games" (Coşkun, 2006, pp. 62-63, 89). The idea of the fourth game as a supplementary game came to my mind in 2007. This supplementary game was successfully applied in various activities. The rules of the game must be brief, simple and easy to understand.

Targets of the activity

Students who take part in this activity,

1. Will have the necessary information on the educational marble game.

2. Will know the importance of the educational marble game in learning a language.

3. Will know the names of the important kitchen appliances in Turkish, German and English.

4. They may write sentences, and brief texts with the words they have learned.

5. They may conduct a dialogue related with the subjects. 
Target group: Students of Hacettepe University in Ankara, Faculty of Education, Department of Foreign Language Education, Division of English LanguageTeaching, who take the German as a second foreign language.

Organizer (games master): Coşkun, the author himself.

\section{THE FLOW CHART OF THE ACTIVITY GAME OF MARBLES}

The teaching and learning processes for the lesson where educational games are used should be planned in detail.

Table 1. The Flow Chart of the Activities.

\begin{tabular}{|c|c|c|c|c|}
\hline Steps & Duration & Activities of the games master and the participants & $\begin{array}{l}\text { Method / } \\
\text { Technique }\end{array}$ & Medium \\
\hline 1 & 5 Min. & $\begin{array}{l}\text { Coskun tells the students that today they will try the } \\
\text { game of marbles. The subject is kitchen appliances }\end{array}$ & & $\begin{array}{l}\text { Game of } \\
\text { marbles and } \\
\text { kitchen posters }\end{array}$ \\
\hline 2 & 5 Min. & $\begin{array}{l}\text { The participants label their name plates in three } \\
\text { languages and fix them on their collars. } \\
\text { (e.g.: My name is ................). }\end{array}$ & $\begin{array}{l}\text { Individual } \\
\text { work }\end{array}$ & $\begin{array}{l}\text { Name plates, } \\
\text { pin and } \\
\text { writing mat. }\end{array}$ \\
\hline 3 & 5 Min. & $\begin{array}{l}\text { Groups of four to five students are formed and the } \\
\text { participants sit at desks. }\end{array}$ & & \\
\hline 4 & 5 Min. & The Bosch-game of marbles-case is distributed. & & $\begin{array}{l}\text { Game of } \\
\text { marbles }\end{array}$ \\
\hline 5 & 10 Min. & $\begin{array}{l}\text { The Bosch-game of marbles-case is opened and the } \\
\text { stones are put on the game board. }\end{array}$ & $\begin{array}{l}\text { Group } \\
\text { work }\end{array}$ & $\begin{array}{l}\text { Game of } \\
\text { marbles case } \\
\text { and stones }\end{array}$ \\
\hline 6 & 5 Min. & $\begin{array}{l}\text { The sequence of the players and the referee is } \\
\text { determined with the dice (The person who throws } \\
\text { the smallest number becomes the referee) }\end{array}$ & & Dies \\
\hline 7 & 5 Min. & $\begin{array}{l}\text { Coşkun visits each group and explains the game } \\
\text { rules if questions arise. (The students have already } \\
\text { learned the rules at university) }\end{array}$ & & \\
\hline 8 & 20 Min. & $\begin{array}{l}\text { The list of referees is distributed. Each referee writes } \\
\text { the kitchen appliances names down in Turkish, English } \\
\text { and German with the stones that have been won. }\end{array}$ & $\begin{array}{l}\text { Group } \\
\text { work }\end{array}$ & Referee list \\
\hline 9 & 5 Min. & $\begin{array}{l}\text { The participants lay the game case and stones on the } \\
\text { table. They sit down at the desks that are ready for } \\
\text { the plenum. The referees show the results. }\end{array}$ & $\begin{array}{l}\text { Circle / } \\
\text { Recitation }\end{array}$ & Referee list \\
\hline 10 & 20 Min. & $\begin{array}{l}\text { The players sit down at the desks. Author gives } \\
\text { group A the students sheet and the first } 12 \text { flash card } \\
\text { pictures. He also gives group B the students' sheet } \\
\text { and the last } 12 \text { flash card pictures The participants fill } \\
\text { in the blanks with the } 12 \text { Turkish and English words. }\end{array}$ & $\begin{array}{l}\text { Circle / } \\
\text { Recitation }\end{array}$ & $\begin{array}{l}\text { Pictures and } \\
\text { student- } \\
\text { sentence-list }\end{array}$ \\
\hline 11 & 5 Min. & The participants again sit down at the plenum desks. & $\begin{array}{l}\text { Circle / } \\
\text { Recitation }\end{array}$ & \\
\hline 12 & 10 Min. & $\begin{array}{l}\text { Each group hangs the flash cards on the clothesline } \\
\text { and reads and explains the writings. }\end{array}$ & & $\begin{array}{l}\text { Clothesline, } \\
\text { clips, pictures } \\
\text { and work lists }\end{array}$ \\
\hline
\end{tabular}




\begin{tabular}{lllll}
\hline 13 & 10 Min. & $\begin{array}{l}\text { The participants again sit at their desks and solve the } \\
\text { puzzle. }\end{array}$ & $\begin{array}{l}\text { Individual } \\
\text { work }\end{array}$ & $\begin{array}{l}\text { Puzzle and } \\
\text { writing } \\
\text { material }\end{array}$ \\
\hline 14 & 5 Min. & $\begin{array}{l}\text { The participants again sit at their desks for the } \\
\text { plenum and talk about the problems of solving } \\
\text { puzzles (the solutions are distributed if necessary). }\end{array}$ & $\begin{array}{l}\text { Circle / } \\
\text { Recitation }\end{array}$ & $\begin{array}{l}\text { Work sheets } \\
\text { for the group } \\
\text { work/ } \\
\text { individual } \\
\text { work }\end{array}$ \\
\hline 15 & 5 Min. & $\begin{array}{l}\text { The marble game is evaluated. The completion of the } \\
\text { activity is announced. Coşkun thanks them for their } \\
\text { cooperation }\end{array}$ & $\begin{array}{l}\text { Circle / } \\
\text { Recitation }\end{array}$ \\
\hline \\
$\begin{array}{l}\text { Total of } \\
120 \text { Min. }\end{array}$
\end{tabular}
Source: Author.

\section{WORD LISTS}

In order to facilitate communication in the foreign language teaching where educational games were used, a table containing the proper names, personal pronouns, nouns, verbs, adjectives and expressions used in the games should be prepared. As I stated above, the target group is taking German as a second foreign language for two hours a week for three semesters. This period is very short to actively learn a foreign language. The explanations and lists should be given in three languages for the students to benefit from the languages they know (have learned).

Table 2. The Important Vocabulary.

\begin{tabular}{lll}
\hline Türkçe & Deutsch & English \\
\hline Özel isimler & Eigennamen & Proper names \\
\hline Kerim & Kerim & Kerim \\
Claudia & Claudia & Claudia \\
Derin & Derin & Derin \\
\hline
\end{tabular}

Source: Author.

As seen in this list, the proper names are the same in all languages and they are generally not translated. Sometimes the phonetic pronunciation of the names is adapted to the related alphabet. In foreign language lessons it is a relief for students, if they recognize proper names in dialogues, texts and so on.

Table 3. Personal pronouns.

\begin{tabular}{lll}
\hline Türkçe & Deutsch & English \\
\hline Sahis zamirleri & Personalpronomen & Personal pronouns \\
\hline ben & ich & I \\
sen & du & you \\
o (erkek, kadın, cansız) & er / sie / es & he / she / it \\
biz & wir & we \\
siz & ihr & you \\
onlar & sie & they \\
siz & Sie & you \\
\hline Cins isimler & Substantive (der, die, das/die) & Nouns (the) \\
\hline
\end{tabular}




\begin{tabular}{lll}
\hline çay & der Tee & Tea \\
karar & die Entscheidung & decision \\
hakem & der Schiedsrichter & referee \\
hakem (kadın) & die Schiedsrichterin & referee \\
oyuncu & der Spieler & player \\
oyuncu (kadın) & die Spielerin & player \\
oyun tahtası & das Spielbrett & game board \\
rakip & der Gegner & opponent \\
rakip (kadın) & die Gegnerin & opponent \\
resim & das Bild & picture \\
şans & die Möglichkeit & chance \\
zar & der Würfel & dice \\
oyun alanı & das Spielfeld & game field \\
bardak & das Glas & glass \\
çanta & der Koffer & case \\
oyun kuralı & die Spielregel & rule of the game \\
diyalog & der Dialog & dialog \\
kahve & der Kaffee & coffee \\
tur & die Runde & tour \\
masa & der Tisch & table \\
üye & das Mitglied & member \\
grup & die Gruppe & group \\
alt grup & die Untergruppe & subgroup \\
numara & die Nummer & number \\
harf & der Buchstabe & letter \\
oyuncak & das Spielzeug & toy \\
misket & die Murmel & marble \\
kenar & der Rand & edge \\
\hline Soure & & \\
\hline
\end{tabular}

Source: Author.

It is believed that every educational game must include a word list that consists of personal pronouns, adjectives, verbs, nouns and simple and detailed speech tools. This list should be prepared by taking into consideration the target group. Below you will see a word list for the game of marbles.

Table 4. The Important Verbs, Adjectives and Expressions.

\begin{tabular}{lll}
\hline Eylemler & Verbs & Verben \\
\hline gelmek & kommen & to come \\
hazırlamak & vorbereiten & to prepare \\
sahip olmak & haben & to have \\
işaretlemek & kennzeichnen & to mark \\
almak & nehmen & to take \\
koymak (üstüne) & legen & to put (on) \\
üstünde bulunmak & liegen & to lie on \\
zar atmak & würfeln & to throw dice \\
yapmak & machen & to do \\
yapmalı & sollen & should / have to \\
aktarmak & umlegen & to transfer \\
oturmak & sitzen & to sit \\
dağitmak & verteilen & to distribute \\
becermek & schaffen & to succeed \\
zorunda olmak & müssen & must \\
numaralamak & nummerieren & to number \\
yuvarlanmak & rollen & to roll \\
\hline
\end{tabular}




\begin{tabular}{lll}
\hline Sıfatlar & Adjektive & Adjectives \\
\hline küçük & klein & small \\
$\ldots$.dan küçük & kleiner als & smaller than \\
en küçük & am kleinsten & smallest \\
büyük & groß & big \\
...dan büyük & größer als & bigger than \\
en büyük & am größten & biggest \\
yavaş & langsam & slow \\
hyzlı & schnell & quick \\
yuvarlak & rund & round \\
düz & flach & flat \\
derin & tief & deep \\
\hline
\end{tabular}

\begin{tabular}{|c|c|c|}
\hline Konuşma Kalıpları & Redemittel & Expressions \\
\hline Çay demlemek & Tee aufsetzen & to brew tea \\
\hline Sira bende. & Ich bin dran./ an der Reihe. & It is my turn. \\
\hline Nasıl devam ediyor? & Wie geht es weiter? & How does it go on? \\
\hline Dur! Dur! & Halt! Halt! & Stop! Stop! \\
\hline Bu olmaz. & Das geht nicht. & This does not work. \\
\hline Hedefe ulaşmıș olmak & am Ziel sein & to have reached the target \\
\hline $\begin{array}{l}\text { Bir şeyi bir şeyin üstüne } \\
\text { koymak }\end{array}$ & $\begin{array}{l}\text { etwas auf etwas legen } \\
\text { Etwas liegt auf etwas. }\end{array}$ & $\begin{array}{l}\text { to put something on top of } \\
\text { something }\end{array}$ \\
\hline $\begin{array}{l}\text { Bir şeyin bir şeyin üstünde } \\
\text { olmasi. } \\
\text { Gözünüz aydın! (Tebrikler!) }\end{array}$ & Herzlichen Glückwunsch! & $\begin{array}{l}\text { Something is on top of something. } \\
\text { Congratulations! }\end{array}$ \\
\hline
\end{tabular}

Table 5. Sözcük Listesi / Wortliste / Word List / Mutfak Aletleri / Küchengräte / Kitchen Appliances.

\begin{tabular}{|l|l|l|l|l|}
\hline Nr. & Resim / Bild / Picture & Türkisch & Deutsch & English \\
\hline 1 & & Bardak & das Glas & Glass \\
\hline 2 & & Biçak & das Messer & Knife \\
\hline 3 & & Bulaşık makinesi & die Spülmaschine & Dishwasher \\
\hline 4 & & & & \\
\hline
\end{tabular}




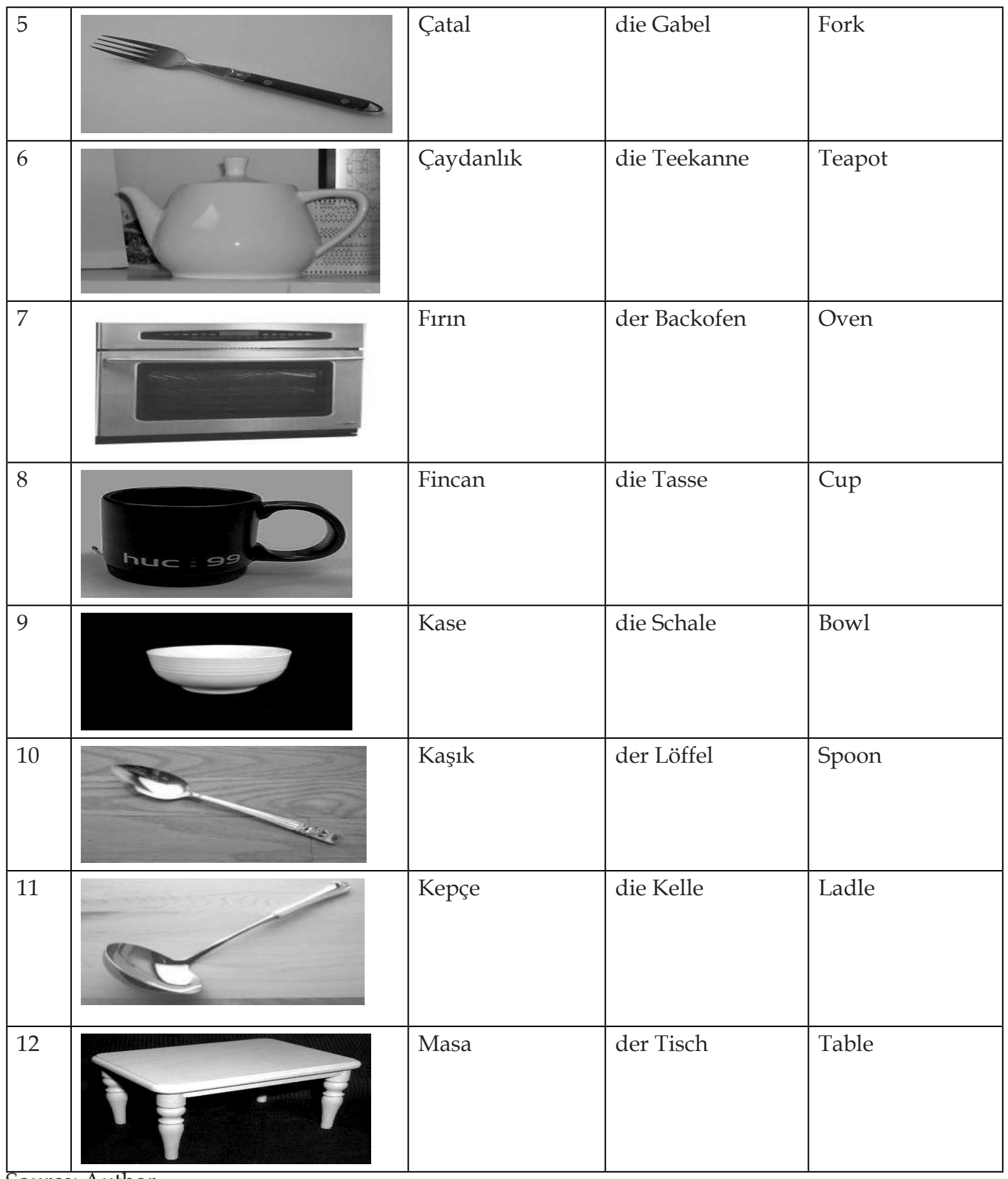

Source: Author.

\section{TRAINING MATERIALS FOR MEMORIZING THE VOCABULARY}

It is possible to teach the names of kitchen appliances outside of game variations with the use of different exercises. Zu diesem Zwecke habe ich einige Übungsmaterialien entwickelt. Als Beispiel finden Sie im Anhang Übungsblätter „Word Salada" und "Search Puzzle". The following These reading and writing exercises can be added, or the students may participate spontaneously. 


\section{DISCUSSION AND CONCLUSION}

In Turkish primary, middle and secondary schools, English is the foreign language of first choice. Secondary school students with good grades learn English as their first foreign language. Students with lower grades at that stage usually learn German or French. In teacher training, German or French is taken by student language teachers as their second foreign language. This gives rise to the question of how can the situation of the second foreign language be quantitatively and qualitatively improved in Turkey. Experience has shown that the situation of the second foreign language can be quantitatively and qualitatively improved in Turkey if the parents campaign for better teaching, necessary administrative measures are taken and lessons made more attractive with the support of foreign mediating institutions methodically and didactically. It is therefore of great significance that Turkish parents, Turkish educational institutions and foreign mediating institutions together promote better foreign language teaching.

Most Students in Turkey choose English as a foreign language. However, today English is not a foreign language. English is a language everybody should know. Turkish families make an economic sacrifice for their children in order for them to learn foreign languages. Therefore The Ministry of National Education has taken the initiative to start lessons in German, French, Russian, Spanish, Japanese and ethnic languages in Turkey in addition to English (Eurydice, 2010, p177). For example, two languages are taught in Anatolian High Schools. The Higher Education Council has added second foreign language classes for three semesters to the foreign language teaching programs. Private educational institutions said that more than one foreign language is being taught in their schools (YÖK, 2007, pp. 215-219; Kavak, 2009, pp. 27-36; Takkaç, 2014, pp. 44-54). German representative bodies try very hard to make German teaching more attractive.

In spite of the measues mentioned above, the results in foreign language teaching are not satisfactory. There are, of course, various possibilities of making German language teaching attractive. One of these possibilities is the development and use of suitable teaching materials. In that connection, I have here attempted to relate my experience with the teaching game "Marbles".

The experiences with the marble games showed it is possible to strengthen interest in and raise the level of knowledge of the German language through the use of educational games in Turkey. Because German is offered mostly as an elective subject, German lessons should be made more attractive and interesting to the students, for which in-service training might be necessary.

It is very important that educational games should be prepared in the light of social-pedagogical viewpoints and that they should be embedded in recreational activities, pre-school classes, primary and secondary education levels, universities and further education for teachers. The educational games should be such that they can easily be modified according to various target groups. The educational games should be prepared to be used in pre-schools to teach colours, numbers, single words and easy forms of expressions. For children of pre-school age, it is also important that they do many things with their hands (Coşkun, 2013, pp. 168-169). 
I would like to make the following recommendations based on my experience acquired during the implementation of the marble game for the successful application of the educational games in class.

Proposals for administrative measures and for German-Turkish cooperation:

1. The present 2 hours per week should be increased to 6 .

2. The grade in German should be taken into account when teachers are being employed.

3. German-Turkish cooperation should be expanded.

4. New teaching materials and text books should be designed.

Proposals in relation to teaching games:

1. Educational games should be developed to be used in language classes.

2. Educational games should be supported with additional games.

3. Educational materials (word lists, puzzles, dialogues, practices, etc.) should be developed.

4. The teachers should be provided with the necessary information during the in-service courses.

5. Parents and students should be informed that the educational games especially support the development of speaking skills.

6. It should be explained that educational games are supported by the Common European Framework of Reference for Languages.

7. It should be highlighted that the educational games are helpful in practicing the functional phrases learned.

8. Facilities for the implementation of educational games should be created in educational institutions. (The facility, tables and chairs should be suitable for group studies.)

9. Coordination should be established between the teachers who work with educational games.

10. The educational games developed should be sent to those who show interest in them.

\section{REFERENCES}

Annual report of the Turkish-German Cultural Advisory Board Ankara for the period from 01.01.2013 to 31.12.2013.

Bayraktaroğlu, S. (2014). Neden Yabancı Dil Eğitiminde Başarılı Olamıoruz? [Why can not we be successful in foreign language teaching? ]. In: A. Sarıçoban, \& H. Öz (Eds.), What should be trends in foreign language education in Turkey. Ankara: Hacettepe Üniversitesi Yayınları.

Coşkun, H. (2013). The importance of educational marble games in teaching German. Education Research - Eurasian Journal of Educational Research, 53, 151-174.

Coşkun H. (2006). Oyunlarla dil öğretimi, Spiele im Sprachunterricht, Learning Languages Through Games, Türkçe - İngilizce - Almanca. Ankara: CTB Yayınları,.

Demircan, Ö. (2014).Yabancı Dil Öğretimi: Değişen Bir Şey Yok! [Foreign Language Teaching: Nothing has changed !]. Öğretmen Dünyast, Yıl: 35 / Şubat 2014, Sayı: 410. Ankara.

Diem, W. (2004). Die schönsten Murmelspiele [The Nicest Games of Marble]. Classical Games. Kempen: Moses Verlag publication.

Kavak, Y. (2009). Öğretmen yetiştirme modelleri ve yeniden yapılanma çalışmaları [Teacher Training 
Models and Reconstruction Studies]. Türkiye'de Öğretmen Yetiştirmeye Genel Bakış - Eğitimde Yansımalar: IX, Eğitim Araştırma Geliştirme Vakfi Yayınlan No 11, Ankara: Educational foundation publication, 27-36.

Takkaç, M. (2014). Türkiye'de Öğretmen Yetiştirme Programları ve Sorunları [Teacher Training Programs in Turkey and Problems]. In: A. Sarıçoban, \& H. Öz (Eds.), What should be trends in forgeign language education in Turkey. Ankara: Hacettepe Üniversitesi Yayınları.

Yıldırım, A., \& Şimşek, H. (2006). Sosyal bilimlerde nitel araştırma yöntemleri [Qualitative research methods in social sciences]. Ankara: Seçkin Yayıncılık.

YÖK. (2007). Öğretmen yetiştirme ve eğitim fakülteleri (1982 - 2007) [Teacher training an faculties of education]. Ankara: Yükseköğretim Kurulu (Higher Education).

\section{ANNEX}

Sözcük salatasi / wortsalat / word salad Mutfak aletleri / küchengeräte / kitchen appliances

\section{Table 6. Sözcük Salatası / Wortsalat / Word Salad. Mutfak Aletleri / Küchengräte / Kitchen Appliances.}

\begin{tabular}{|c|c|c|}
\hline Türkçe & Deutsch & English \\
\hline $\begin{array}{l}\text { Bu alıştırma iki sayfadan } \\
\text { oluşmaktadır. Birinci say- } \\
\text { fada bir konuya ait söz- } \\
\text { cükler üç dilde karışı } \\
\text { bir düzende verilir. İkinci } \\
\text { sayfada ise üç kolonlu ve } \\
24 \text { aralıklı bir tablo verilir. } \\
\text { Öğrencilerden sözcükleri } \\
\text { bir dilde seçip alfabetik } \\
\text { tabloya yerleştirmeleri ve } \\
\text { daha sonra seçilen bu söz- } \\
\text { cüklerin karşılıklarını diğer } \\
\text { iki dilde yazmaları istenir. } \\
\text { Alfabetik sıranın yapılacağı } \\
\text { dilin önceden belirlenmesi, } \\
\text { öğrencilerin çalışmalarını } \\
\text { ve öğretmenin kontrolünü } \\
\text { kolaylasstıracaktır. }\end{array}$ & $\begin{array}{l}\text { Diese Übung besteht aus zwei Sei- } \\
\text { ten. Auf der ersten Seite befinden } \\
\text { sich Wörter in drei Sprachen in } \\
\text { gemischter Form. Auf der zweiten } \\
\text { Seite gibt es eine Tabelle, die aus } \\
\text { drei Spalten und } 24 \text { Zeilen besteht. } \\
\text { Von den Schülern wird erwartet, die } \\
\text { Wörter in einer Sprache auszusu- } \\
\text { chen, diese dann alphabetisch in die } \\
\text { Tabelle einzutragen und anschlie- } \\
\text { ßend die Bedeutung dieser Wörter } \\
\text { in den anderen zwei Sprachen in } \\
\text { die Tabelle zu schreiben. Die Arbeit } \\
\text { der Schüler und die Kontrolle des } \\
\text { Lehrers werden erleichtert, wenn } \\
\text { vorher angegeben wird, in welcher } \\
\text { Sprache die Wörter alphabethisch } \\
\text { geordnet werden sollen. }\end{array}$ & $\begin{array}{l}\text { This exercise consists of two } \\
\text { pages. On the first page, the } \\
\text { words pertaining to a subject } \\
\text { are given in three languages in } \\
\text { a mixed manner. On the second } \\
\text { page a table with three columns } \\
\text { and } 24 \text { spaces is given. Students } \\
\text { are asked to choose the words } \\
\text { in one language and then fill } \\
\text { them alphabetically in the ta- } \\
\text { ble and write the correspond- } \\
\text { ing meanings in the other two } \\
\text { languages. Determining, in ad- } \\
\text { vance, the language in which } \\
\text { the alphabetic listing will be } \\
\text { made will simplify the tasks of } \\
\text { the students and teacher's work } \\
\text { of checking them. }\end{array}$ \\
\hline
\end{tabular}

Glass Çaydanlık Knife Karaffe die Zuckerdose Ladle Termos die Spülmaschine Apron Strainer Salt shaker Sandalye das Messer der Kühlschrank die Gabel Fork Çatal der Teekanne der Salzstreuer Teapot Furın Sugar bowl der Backofen Table Oven Fincan Sürahi Masa Bulaşık makinesi die Kelle die Tasse die Schürze Cup Tava die Schale Bowl Kaşık der Löffel Şekerlik Tabak der Tisch Önlük Mikro dalga firın Refrigerator Raf das Regal Shelf Dishwasher Spoon der Stuhl der Teller Biçak Thermos flask die Kase Decanter Süzgeç das Sieb Kepçe die Bratpfanne die Mikrowelle Dish Frying-Pan Microwave das Glas Tencere der Kochtopf Chair Saucepan Buzdolabi die Thermosflasche Bardak Tuzluk

Source: Coşkun, 2006, p. 56. 
Sözcük salatasi / wortsalat / word salad

Mutfak aletleri / küchengeräte / kitchen appliances

Önce sol sayfada yer alan kutudaki Türkçe sözcükleri seçiniz ve alfabetik siraya göre aşağıdaki tabloya yazınız. Daha sonra Almanca ve İngilizce anlamlarını yaziniz.

First choose the Turkish words in the lefthand column and write them in alphabetical order into the tablen. Then write their meanings in German and English.

First, choose the Turkish words from the box on the left page and list them alphabetically in the table below. Then, write their meanings in German and English.

Table 7. Student Sheet.

\begin{tabular}{|l|l|l|l|}
\hline Nr. & Türkçe & Deutsch & English \\
\hline 01 & & & \\
\hline 02 & & & \\
\hline 03 & & & \\
\hline 04 & & & \\
\hline 05 & & & \\
\hline 06 & & & \\
\hline 07 & & & \\
\hline 08 & & & \\
\hline 09 & & & \\
\hline 10 & & & \\
\hline 11 & & & \\
\hline 12 & & & \\
\hline 13 & & & \\
\hline 14 & & & \\
\hline 15 & & & \\
\hline 16 & & & \\
\hline 17 & & & \\
\hline 18 & & & \\
\hline 19 & & & \\
\hline 20 & & & \\
\hline 21 & & & \\
\hline 22 & & & \\
\hline 23 & & & \\
\hline 24 & & & \\
\hline
\end{tabular}

Source: Coşkun, 2006, p. 57.

Mutfak aletleri / küchengeräte / kitchen appliances

Sözcük avi bulmaca / such - rätsel / search puzzle

Kare bulmacada 8 Türkçe, 8 Almanca ve 8 İngilizce sözcük gizlidir.

Bunları bulabilir misiniz? Bu sözcükleri üç renkte işaretleyiniz! Türkçe sözcükleri kırmızı, Almanca sözcükleri mavi ve İngilizce sözcükleri yeşil.

Kesişme noktalarındaki harfler iki renkli olabilir.

Im Quadraträtsel sind 8 türkische, 8 deutsche und 8 englische Wörter versteckt. 
Können Sie diese finden? Markieren Sie diese Wörter in drei Farben! Türkische Wörter in Rot, deutsche Wörter in Blau und englische Wörter in Grün.

Die Buchstaben an Überschneidungspunkten können zweifarbig sein.

8 Turkish, 8 German and 8 English words are hidden in the square puzzle.

Can you find them?

Mark these words in three colors! Turkish words in red, German words in blue and English words in green.

The letters at the intersections may have two colors.

Tabele 8. Student Sheet.

\begin{tabular}{|c|c|c|c|c|c|c|c|c|c|c|c|c|c|c|c|c|c|c|c|c|}
\hline 00 & 01 & 2 & 3 & 04 & 05 & 06 & 07 & 08 & 09 & 10 & 11 & 12 & 13 & 14 & 15 & 16 & 17 & 18 & 19 & 20 \\
\hline 01 & C & $\mathrm{H}$ & A & I & $\mathrm{R}$ & $\mathrm{P}$ & $\mathrm{O}$ & $\mathrm{I}$ & $\mathrm{U}$ & $Y$ & $\mathrm{~T}$ & $\mathrm{R}$ & $\mathrm{E}$ & $W$ & $\mathrm{Q}$ & A & $S$ & $\mathrm{~F}$ & $G$ & $\mathbf{R}$ \\
\hline 02 & $\overline{\mathrm{U}}$ & $\overline{\mathrm{H}}$ & $\overline{\mathrm{J}}$ & $\mathrm{K}$ & $\mathrm{L}$ & Ş & & $\breve{G}$ & $P$ & $\mathrm{O}$ & & $\overline{\mathrm{U}}$ & $\bar{Y}$ & Y & $\mathrm{R}$ & $\overline{\mathrm{U}}$ & $\mathrm{T}$ & $\mathrm{A}$ & $\overline{\mathrm{V}}$ & $\mathrm{A}$ \\
\hline 03 & $P$ & $\mathrm{~N}$ & K & I & $\mathrm{T}$ & $\mathrm{T}$ & $\mathrm{E}$ & $\mathrm{L}$ & $\mathrm{M}$ & $\mathrm{N}$ & B & $\mathrm{V}$ & $C$ & $X$ & $\mathrm{Z}$ & V & E & K & $\mathrm{I}$ & $F$ \\
\hline 04 & $\mathrm{~J}$ & $\mathrm{H}$ & $\mathrm{A}$ & $\bar{V}$ & $\bar{F}$ & $\mathrm{E}$ & I & $\overline{\mathrm{U}}$ & $Y$ & $\mathrm{~T}$ & $\mathrm{R}$ & $E$ & $\mathrm{~W}$ & $\mathrm{D}$ & $S$ & $\mathrm{~A}$ & $\mathrm{~N}$ & $\mathrm{~V}$ & $\mathrm{H}$ & $\mathrm{J}$ \\
\hline 05 & $\mathrm{~K}$ & $\mathrm{H}$ & $\mathrm{R}$ & $\mathrm{L}$ & $\mathrm{K}$ & $\mathrm{R}$ & $\bar{I}$ & $Y$ & $\mathrm{~T}$ & $\mathrm{R}$ & E & W & $\mathrm{Q}$ & $\mathrm{N}$ & B & V & C & $X$ & K & I \\
\hline 06 & G & $\mathrm{L}$ & A & $S$ & Ö & $\mathbf{M}$ & $\mathrm{A}$ & $S$ & A & $\mathrm{M}$ & B & $\mathrm{V}$ & $\mathrm{C}$ & Ş & $\mathrm{K}$ & $\mathrm{H}$ & $E$ & $\bar{J}$ & G & $F$ \\
\hline 07 & $\mathrm{~J}$ & I & $\mathrm{F}$ & $\mathrm{L}$ & $\mathrm{J}$ & $\mathrm{O}$ & I & $\mathrm{O}$ & $E$ & $\mathrm{R}$ & $\mathrm{T}$ & U & I & $\mathrm{E}$ & $\mathrm{O}$ & I & $\mathrm{R}$ & $\mathrm{T}$ & $\mathrm{R}$ & $\mathbf{M}$ \\
\hline 08 & $F$ & B & $F$ & $\mathrm{U}$ & $\mathrm{K}$ & $S$ & $\mathrm{Q}$ & W & $E$ & $\mathrm{R}$ & $\mathrm{T}$ & $Y$ & I & $\mathbf{K}$ & $\mathrm{A}$ & $S$ & $\mathrm{E}$ & I & $\mathrm{O}$ & I \\
\hline 09 & $\mathrm{O}$ & $\mathrm{V}$ & $\mathrm{E}$ & $\mathrm{N}$ & B & $\mathrm{N}$ & $\mathrm{V}$ & $S$ & I & $\mathrm{E}$ & B & $\mathrm{Z}$ & V & E & B & $\mathrm{N}$ & $\mathrm{M}$ & $\ddot{O}$ & Ç & $C$ \\
\hline 10 & $\mathrm{R}$ & $\mathrm{M}$ & B & $\mathrm{V}$ & $\mathrm{C}$ & $G$ & $\mathrm{R}$ & A & I & K & $\mathrm{I}$ & $\mathrm{H}$ & $\mathrm{F}$ & $\mathrm{R}$ & $\mathrm{D}$ & $\mathrm{K}$ & $\mathrm{L}$ & Ş & Ş & $\mathrm{R}$ \\
\hline 11 & $\mathrm{~K}$ & $\mathrm{~J}$ & $\mathrm{~L}$ & Ş & $\overline{\mathrm{I}}$ & $\breve{G}$ & $\mathrm{O}$ & $\mathrm{L}$ & $\mathrm{U}$ & $\mathrm{T}$ & $\mathrm{R}$ & $E$ & $\mathrm{~W}$ & $\mathrm{~L}$ & A & D & $\mathrm{L}$ & $E$ & $X$ & $\mathrm{O}$ \\
\hline 12 & $\mathrm{~V}$ & B & $\mathrm{N}$ & $\mathrm{M}$ & Ö & Ö & Ö & $\mathrm{T}$ & $\mathrm{Q}$ & $W$ & $\mathrm{R}$ & $Y$ & $\mathrm{U}$ & $\dot{\mathrm{I}}$ & G & I & $\bar{J}$ & $\mathrm{~K}$ & L & $\bar{W}$ \\
\hline 13 & $\mathrm{Q}$ & $\mathrm{W}$ & $S$ & $\mathrm{E}$ & $\mathrm{R}$ & $\mathrm{T}$ & $Y$ & $Z$ & $Y$ & I & $\mathrm{O}$ & $\mathrm{O}$ & $\mathrm{P}$ & $\mathrm{K}$ & $\mathrm{Z}$ & $S$ & $C$ & $\mathrm{~V}$ & B & A \\
\hline 14 & $\mathrm{M}$ & $S$ & $\mathrm{P}$ & $\ddot{\mathrm{U}}$ & $\mathrm{L}$ & $\mathrm{M}$ & A & $S$ & $C$ & $\mathrm{H}$ & I & $\mathrm{N}$ & $\mathrm{E}$ & Ö & Ç & $\mathrm{H}$ & Ş & K & $\mathrm{J}$ & $\mathrm{V}$ \\
\hline 15 & I & $\mathrm{U}$ & $\mathrm{O}$ & $\mathrm{T}$ & $\mathrm{R}$ & $E$ & $W$ & $\mathrm{~T}$ & $x$ & $\mathrm{~V}$ & $\mathrm{H}$ & $\mathrm{J}$ & $\mathrm{K}$ & $B$ & $\mathrm{H}$ & $Y$ & $\mathrm{~N}$ & $\mathrm{~T}$ & G & $\mathrm{E}$ \\
\hline 16 & B & $\mathrm{V}$ & $\mathrm{O}$ & $\mathrm{N}$ & $\mathrm{H}$ & $Y$ & $\mathrm{~T}$ & $\mathrm{R}$ & B & G & $\mathrm{R}$ & G & $\mathrm{T}$ & $\mathrm{H}$ & $Y$ & $\mathrm{U}$ & $\mathrm{J}$ & $\mathrm{M}$ & $\mathrm{K}$ & $\mathrm{O}$ \\
\hline 17 & I & $\mathrm{N}$ & $\mathrm{N}$ & $\mathrm{J}$ & K & $\mathrm{T}$ & E & E & K & A & $\mathrm{N}$ & $\mathrm{N}$ & E & $\mathrm{E}$ & D & C & V & $\mathrm{F}$ & $\mathrm{R}$ & V \\
\hline 18 & Ç & $Y$ & $\mathrm{H}$ & $\mathrm{N}$ & $\mathrm{M}$ & $\mathrm{J}$ & $\mathrm{U}$ & $\mathrm{U}$ & I & Ö & Ö & $\mathrm{L}$ & $\mathrm{O}$ & Ç & I & $\mathrm{K}$ & Ö & $\mathrm{O}$ & $\mathrm{L}$ & $\mathrm{E}$ \\
\hline 19 & A & $\mathrm{O}$ & $\mathrm{L}$ & Ç & K & I & $\mathrm{U}$ & $E$ & $\mathrm{R}$ & $\mathrm{T}$ & $\mathrm{H}$ & B & $\mathrm{N}$ & $\mathrm{H}$ & Y & $\mathrm{N}$ & $\mathrm{J}$ & U & $\mathrm{M}$ & $\mathrm{N}$ \\
\hline 20 & $\mathrm{~K}$ & $\ddot{U}$ & $\mathrm{H}$ & $\mathrm{L}$ & $S$ & $C$ & $\mathrm{H}$ & $\mathrm{R}$ & A & $\mathrm{N}$ & $\mathrm{K}$ & $\mathrm{J}$ & $\mathrm{U}$ & $\mathrm{K}$ & $\mathrm{M}$ & $\mathrm{N}$ & $\mathrm{H}$ & $\mathrm{T}$ & $\mathrm{G}$ & B \\
\hline
\end{tabular}

Source: Coşkun, 2006, p.57.

Kare içinde bulduğunuz Türkçe sözcükleri, alfabetik sıraya göre sağ taraftaki tabloya yerleştiriniz. Daha sonra Türkçe sözcüklerin Almanca ve İngilizce anlamlarını yazınız.

Tragen Sie zuerst die türkischen Wörter, die Sie im Quadrat gefunden haben, alphabetisch in die Liste auf der rechten Seite ein. Dann schreiben Sie bitte die deutschen und englischen Bedeutungen der türkischen Wörter auf.

First, list the Turkish words which you have found in the square alphabetically into the table on the right. Then, please write the meanings of Turkish words in German and in English (Coşkun, 2006, p. 218). 


\section{Mutfak aletleri / küchengeräte / kitchen appliances}

Sözcük avi bulmaca / such - rätsel/ search puzzle

Bu sözcük avı bulmacada 24 sözcük (Mutfak Aletleri) gizlidir. Önce sol sayfadaki Türkçe, Almanca ve İngilizce sözcükleri bulunuz ve daha sonra Türkçe alfabetik sıraya göre aşağıdaki tabloya yazınız.

In diesem Suchrätsel sind 24 Wörter (für Küchengeräte) versteckt. Suchen Sie zuerst die türkischen, deutschen und englischen Wörter auf der linken Seite heraus und tragen Sie diese alphabetisch geordnet (türkisch) in die unten vorhandene Liste ein.

In this search puzzle 24 words (kitchen appliances) are hidden. First, find out the Turkish, German and English words on the left and transfer them alphabetically (in Turkish) into the existing list below.

Table 9. Student Sheet.

\begin{tabular}{|c|c|c|c|}
\hline Nr. & Türkçe & Deutsch & English \\
\hline \multicolumn{4}{|l|}{01} \\
\hline \multicolumn{4}{|l|}{02} \\
\hline \multicolumn{4}{|l|}{03} \\
\hline \multicolumn{4}{|l|}{04} \\
\hline \multicolumn{4}{|l|}{05} \\
\hline \multicolumn{4}{|l|}{06} \\
\hline \multicolumn{4}{|l|}{07} \\
\hline \multicolumn{4}{|l|}{08} \\
\hline \multicolumn{4}{|l|}{09} \\
\hline \multicolumn{4}{|l|}{10} \\
\hline \multicolumn{4}{|l|}{11} \\
\hline \multicolumn{4}{|l|}{12} \\
\hline \multicolumn{4}{|l|}{13} \\
\hline \multicolumn{4}{|l|}{14} \\
\hline \multicolumn{4}{|l|}{15} \\
\hline \multirow{2}{*}{\multicolumn{4}{|c|}{$\frac{16}{17}$}} \\
\hline & & & \\
\hline \multicolumn{4}{|l|}{18} \\
\hline \multirow{2}{*}{\multicolumn{4}{|c|}{19}} \\
\hline \multicolumn{3}{|l|}{20} & \\
\hline \multicolumn{4}{|l|}{21} \\
\hline \multicolumn{4}{|l|}{22} \\
\hline 23 & & & \\
\hline 24 & & & \\
\hline
\end{tabular}

Source: Coşkun, 2006, p. 57. 